\title{
Innovative projects with real options in textile production: evaluation of their effect
}

\author{
Sergey Filin ${ }^{1, *}$, Alexey Yakushev $^{1}$, Zhumahan Myrkhalykov ${ }^{2}$, Vladimir Velikorossov ${ }^{1}$, and \\ Lyubov Chaykovskaya ${ }^{1}$ \\ ${ }^{1}$ Plekhanov Russian University of Economics, Department of Management, 117997, Stremyanny \\ Lane, 36, Moscow, Russian Federation \\ ${ }^{2}$ SILKWAY International University, 160011, Tokayev Street, 27a, Shymkent, Kazakhstan
}

\begin{abstract}
The article raises a relevant topic - increasing the objectivity of assessing the effect of innovative projects with real options in the textile industry. The purpose of this article is to offer recommendations for assessing the effect of innovative projects with real options implemented in the textile industry. The novelty of the article is to identify trends in the development of textile production in Russia and to propose a mathematical model for assessing the effect of innovative projects with real options implemented in textile production. A forecast and an analysis of the main strategic directions of development of the Russian textile industry until 2025 were made. It was concluded that the use of real options changes approaches to innovative projects implemented by textile enterprises, which can lead to a change in the nomenclature and assortment produced within the framework of this project and the enterprise in overall textile products and the extent of its supply.
\end{abstract}

\section{Introduction}

Russia does not have climatic conditions for the production of natural textile raw materials, with the exception of flax and hemp, the production of which is insufficient due to the weak development of this subspecies of activity in agriculture. Russian textile enterprises often have to buy abroad cotton, wool and linen, dyes, accessories, etc. The high cost of imports and currency fluctuations can significantly increase the cost of textile products. The demographic crisis deprived the Russian textile industry of cheap labor, and attracting foreign labor is impractical: as foreign experience shows, moving technologies to places of labor formation is more cost-effective [1].

For the formation of competitive advantages by textile enterprises, it is necessary to create a system of innovative technologies for the production of textiles and products from it. Based on the theory of innovative development, it seems possible to create such technologies due to the presence of the following factors: 1) almost all technologies of the textile industry in the world are mature, there are conditions for changing the technological base. What remains unresolved is which country will own the surplus value of this

\footnotetext{
* Corresponding author: Filin.SA@rea.ru
} 
technological "breakthrough" in the textile industry [1]; 2) the textile industry has detailed technological cycles that can be reduced to simple operations, which makes it a convenient object for building fully automated production facilities in it. This, in turn, provides the opportunity to obtain a synergistic effect through the development of appropriate technologies in other sectors of the economy and allows textile enterprises to form a textile production subject area, knowledge capital and intellectual property [2]

The practical implementation of modernization of the textile industry will require testing of fundamental scientific knowledge and the use of risk reduction techniques for innovative projects to attract investors to their implementation in relation to the characteristics of the textile industry as an industrial type of production [3-9].

According to Rosstat, the capacity of the Russian textile industry market is about 7-10 billion dollars USA [10]. The main trends in the textile industry are currently growing global demand for polyester yarns and fibers. The forecast of the main strategic directions for the development of Russian textile industry until 2025 may be as follows: 1) the formation, according to the Ministry of Industry and Trade of the Russian Federation, of a technological chain of artificial and synthetic fibers with an export orientation and leather materials for the main consumers of such fabrics from these fibers - sewing, shoe, furniture and automotive industries: 2) the increase in the competitive advantages of Russian textile enterprises (TE) in the EU market due to the fact that they are closer to it than suppliers from Asian countries, which significantly reduces both the price and delivery time; 3 ) increasing the efficiency of textile production due to the implementation of state support measures in the framework of the state order of sewing school uniforms and others [11]; 4) use of favorable opportunities for the development of Russian textile production due to the sharply increased role of the fashion industry in recent years [12], including the introduction of innovative textile materials in the creation of model clothes; 5) improving the quality of innovative textile products compared to their analogues at lower cost due to the introduction of high technologies and the organization of high-tech production for innovative textile materials.

\section{Materials and Methods}

The Russian textile industry is competitive mainly in the production of textiles for household utensils and bedding. The main competitive advantage of TE is the introduction of innovations, access to cheap labor and Russian raw materials). Although the Russian textile industry does not have competitive advantages in providing them [1], a significant part of the innovations in the textile industry lies in the field of product policy and the Methodology for Demand and Sales Promotion (MDSP), and the rest of the innovations, even with a high degree of introduction of changes are not based on fundamental scientific knowledge; currently, in the textile industry in Russia, innovative developments are carried out in the field of [13]: 1) modern reinforcing materials for composite structural products based on axial webs and the technology of their manufacture using a series of components from Russian raw materials. The basis of composite materials is an axial technical fabric (a textile material consisting of several layers of threads oriented in different directions); 2) cotton fabrics for industrial use with protective properties against aggressive medium and petroleum products, in particular, filter elements for the chemical industry and housing and communal services for protection against a complex of harmful effects in industrial production and ensuring the safety of working conditions and the employee's health during the entire working time. Moreover, they meet the requirements of the environmental standard ECOTEX 100; 3) tissues with bioactive properties for medical institutions that prevent the growth of microorganisms, protect against bacterial transfer, reduce the risk of contact infection. Moreover, they have increased wear resistance and do not require 
disposal compared to disposable medical products made of synthetic non-woven materials; 4) protecting from radiation when creating space suits and allowing disabled people to expand the boundaries of their world of textiles; 5) space antennas.

Based on the theory of innovative development, it seems possible to create such high technologies due to the following factors: 1) almost all technologies in the textile industry in the world are mature, there are conditions for changing the technological base; 2) the textile industry has detailed technological cycles that can be reduced to simple operations, which makes it a convenient object for building fully automated production facilities in it. This, in turn, provides the possibility of obtaining a synergistic effect through the development of appropriate high technologies in other sectors of the economy and allows TE to form the subject area of textile production, knowledge capital and intellectual property [14], necessary for the effective creation and implementation of appropriate high technology to textile production.

Based on technical and economic feasibility, textile products can be modified by changing their configuration, based on the components of the subject area (an ordered and interconnected set of labor objects in the textile industry in the form of a wide range of woven and non-woven materials, components, connecting knots, etc., from which a textile product is created). The creation of a complex textile product requires the use of several subject areas, for example, on a combination of woven and net materials, components, connecting nodes, etc.

The practical implementation of the modernization of existing Russian TE and the creation of high-tech industries will require testing of fundamental scientific knowledge and the use of techniques related to the methodology of the formation and development of innovative infrastructure in relation to the characteristics of the textile industry as an industrial type of production [3].

For a radical and quick update of the production, technical and technological base on an innovative basis, Russian TE lacks its own investment resources. Textile production in subsidized constituent entities of the Russian Federation is not attractive for external investors due to increased risks [15]. The severity of this problem for external investors can be reduced by using the concept of "real options" (RO) [3-9] when assessing the economic efficiency of innovative projects implemented by TE, when the project analysis includes the search for additional opportunities (synergistic effects that arise when the external conditions of the project are changed; the fact that the manager can change the managerial decision made on the basis of new information [16] and knowledge generated as a result of the project), which is not taken into account in the method of classic investment analysis, which involves the use of a static pattern of actions laid down at the initial stage of project implementation so, the presence of a wide subject area in the textile production of materials and components, justified by relevant knowledge, allows TE to quickly modify a textile product in accordance with market requirements or optimize production and logistics.

Evaluation of innovative projects by the method of real options is based on the assumption that any investment opportunity for TE can be considered as a RO: expanding the subject area of the enterprise allows you to upgrade products or replace components in a relatively short time, which is especially important when import substitution or the emergence of new demand. An additional investment in the design of a textile product should be considered as a RO, providing the possibility of its further modernization.

\section{Results and Discussion}

In [17], an estimate of the projected cost of an investment project (CIP) under conditions of risk and uncertainty by the real option method is presented side. 


$$
C I \underline{P=N P V+V R O,}
$$

where $N \overline{P V \text { is }}$ expected net present value from project implementation; $V R O$ is the value of $\mathrm{RO}$ existing at the enterprise or embedded in the project.

For example, a single basic model for a specific textile product is created, for instance a filter element for the chemical industry and housing and communal services (model clothes, etc.) from a textile material, on the basis of which a gamma of modifications of filters (model clothes, etc.) can be created. Marketers predicted demand for this base model while the demand for other (non-basic) modifications is projected to be insignificant. With some additional investments, when starting an innovation project, the basic model can be quickly finalized for use in the relevant industries and can be made in different modifications, which will expand their nomenclature and assortment, and therefore, increase supply and customer demand.

Example 1. The production of a basic filter model (model clothes, etc.) should bring $\mathrm{NPV}=10$ million rubles at a known discount rate for a given investment design horizon with IRR $=30 \%$. The probability of this event is $\mathrm{R}_{1}=75 \%$, which does not suit investors. Risks that can be realized with a probability of $25 \%$ are known and are systemic. Suppose there are 2 of them, they are mutually exclusive and are realized with probabilities $\mathrm{R}_{2}=$ $15 \%$ and $\mathrm{R}_{3}=10 \%$, respectively. With a slight increase in investment, production becomes more flexible, which allows you to preserve the set values of NPV and IRR due to the implementation of integrated ROs in the project. Investments were also made in increasing the subject areas and capital of knowledge of technical and technical conditions and the acquisition of ROs necessary for the implementation of the project. In this case, taking into account the fact that investments reduce the expected effect of the project, formula (1) will take the form.

$$
\begin{aligned}
& C I \overline{P=N} N V-R O V-I K K O O=\left(R_{1} \bullet N P V_{1}+R_{2} \bullet N P V_{2}+R_{3} \bullet N P V_{3}\right)-R O V-I K K O O= \\
& =(0,75 \cdot 10+0,15 \cdot 10+0,10 \cdot 10)-R O V-I K K O O,
\end{aligned}
$$

where $\mathrm{NPV}_{1}, \mathrm{NPV}_{2}$ and $\mathrm{NPV}_{3}$ are the net present value that the company will receive under the appropriate scenario for the implementation of the innovation project; ROV - the value of the TE-owned or embedded in the project RO discounted for the period of the project implementation; IKKOO - investments in increasing the subject areas and capital of knowledge of TE necessary for the implementation of the project, discounted for the period of the project, In this case, the discount rate due to the use of RO is reduced.

The second group of opportunities characterizes the external side of the innovation project, for example, the implementation of one project makes it possible to implement another project that would not be possible without the completion of the first, or this is about the implementation of one of their mutually exclusive projects. For example, a production area equipped with utilities and intended to organize the production of filters (model clothes, etc.) can be sold or used for this production.

Example 2. The textile industry enterprise solves the technical problem that has arisen: creating a basic model for the projected series of textile products through the implementation of an innovative project, which requires investment in the creation of products, technologies and equipment. The project is accompanied by technical, financial, commercial and innovative (especially at the stage of research and development (R\&D)) risks, in particular, unsuccessful completion of the corresponding stage of work, which makes their further continuation inappropriate or a termination of funding for any reason (even if the work is completed successfully), etc. So, conditions for exiting the project with minimal losses, which is a necessary condition for the investor to enter the project must be 
created. At the same time, investments are made in 3 stages, during which it can be stopped: 1) at the initial time, it is necessary to invest 500 thousand rubles. in $R \& D$, the probability of successful completion of which is $60 \%$, with the most unfavorable outcome, the results of R\&D can be sold for 200 thousand rubles, with a favorable outcome not less than 900 thousand rubles, which means cancellation of the project; 2) if the results of the examination of the results of experimental development (R\&D) are favorable, then at the moment of time the production of the textile product will be deployed, into which 60 million rubles will be invested. If this stage is implemented, the project will generate a profit of 38 million rubles. for 4 years. The probability of customer refusal of products is $2 \%$. In this case, the TE leaves the project, receiving an income of 65 million rubles. from the sale of equipment, product rights and technology; 3 ) given the positive results of R\&D and maintaining favorable conditions for the production of this textile product, TE will invest 2 million rubles. on design and development work. Prototypes should be offered for consideration to external experts, specialists in batch production and potential consumers who will give conclusions on the new textile product. If the outcome of stage 2 is unfavorable, the probability of which will be $20 \%$, the results of design and development work can be sold for 1.2 million rubles. or left in the property for their further use. With an $80 \%$ favorable outcome of stage 2 , in case of cancellation of the project, the results of the stage can be sold for at least 10 million rubles. The stages of using RO to reject an innovation project when making an investment decision are shown in Figure 1.

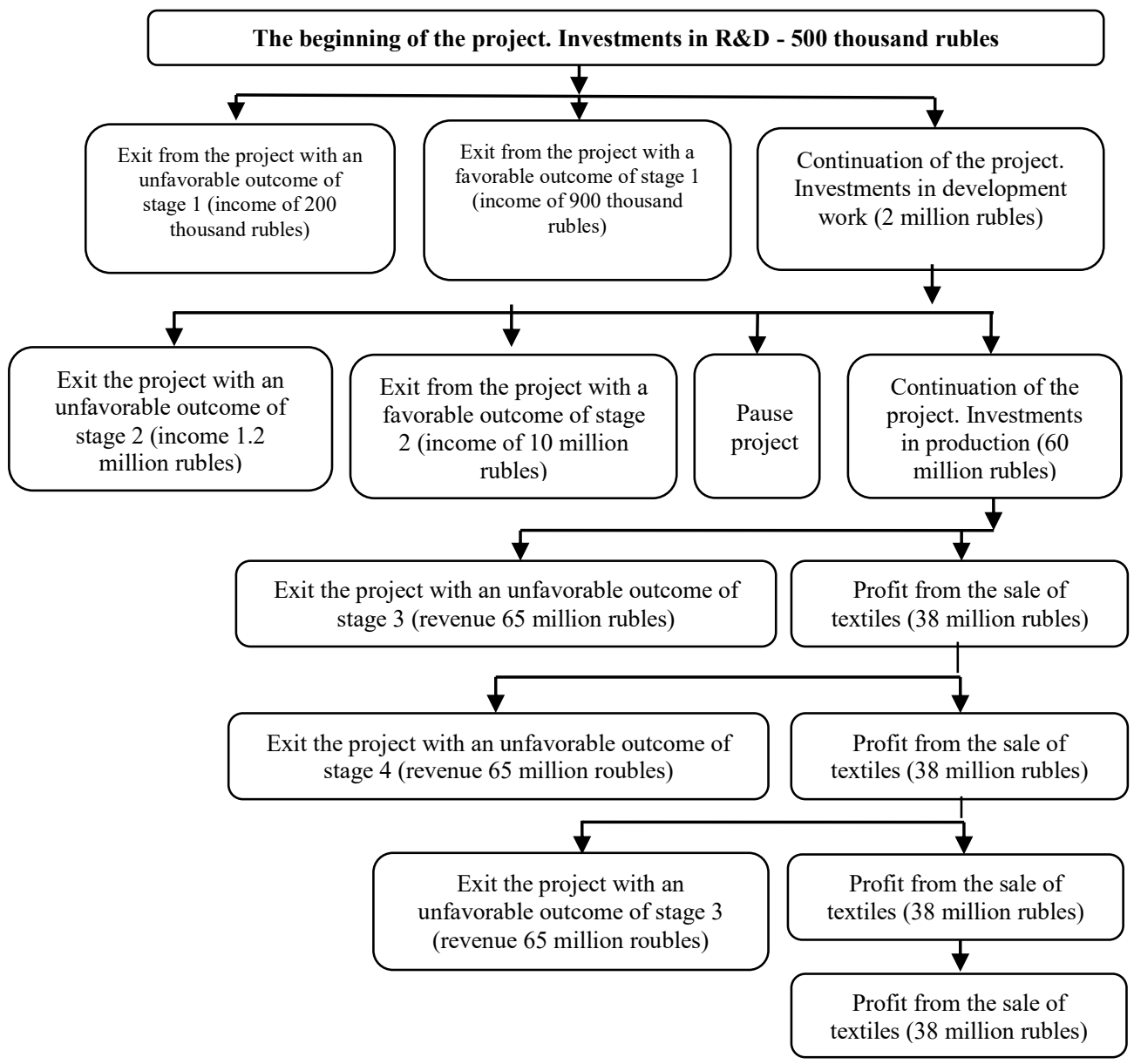


Fig. 1. Stages of using a real option to reject an innovative project.

It is very important for Russian enterprises in the textile industry to use ROs for innovative projects in conditions of investors having a psychological distrust of large and / or long-term private investment. It should be borne in mind that the cost of creating real options in the framework of such a project may prove not justified: for example, the ability to increase the production of textile products (investment in new technologies and equipment) may not be provided by an increase in demand for it [17].

\section{Conclusions}

1. When investing in Russian textile enterprises, investors take into account that investments can be transformed into sunk costs and thereby make investments irreversible, as a result of which they refuse to invest until the prices for textile products under the project provide a profit significantly exceeding long-term investments.

2. Improvement of evaluation of efficiency indicators of innovative projects is aimed at optimizing the modernization capabilities inherent in the design and production technology of textile products by introducing real options into them. The use of real options changes the approaches to innovative projects implemented by enterprises of the textile industry, for example, to assess their effectiveness, adding managerial flexibility to them. This, in turn, allows for a compromise between the cost of projects and managerial flexibility and can lead to a change in the nomenclature and assortment of textile products produced under this project and the enterprise as a whole and the scale of its supply, for example, if marketing research at a certain stage shows that the initial data on these factors do not meet the market requirements for time trend of research, increases the sustainability of development in the circumstances of ever-increasing risks and uncertainty of the external environment during the implementation of an innovative project. The application of methods for assessing the effectiveness of investments used in the fields of activity that are being formed within the framework of new technological structures, in particular, the real options method, can be used to solve the problems of investing in the textile industry that have been formed within the framework of previous technological structures.

\section{References}

1. A.J. Yakushev, The modeling of system contradictions of innovative and postindustrial economy sectors. National economy modernization: problems and solutions. Collective monograph edited by N.A. Adamov (Professor, Moscow, 2014)

2. N.M. Filimonova, L.P. Goncharenko, A.Z. Yakushev, I.R. Fatyanova, News of higher educational institutions. Technology of the textile industry, 4 (358) (2015)

3. T.N. Kashitsyna, L.P. Goncharenko, N.A. Amosova, News of higher educational institutions. Technology of the textile industry, 5 (365) (2016)

4. C. Menassa, F. Pea Mora, N. Pearson, Journal of Construction Engineering and Management - ASCE, 136 (3) (2010)

5. Y. Fan, L. Zhu, Energy Economics, 32 (3) (2010)

6. B. Fernandes, J. Cunha, P. Ferreira, Renewable and Sustainable Energy Reviews, 15 (9) (2011)

7. S.A. Filin, A.ZH. Yakushev, V.V. Velikorossov, B.D. Loshkov and A.K. Khudaibergenov, 2020 2nd International Conference on Pedagogy, Com-munication 
and Sociology (ICPCS 2020). January 6-7 2020. Bangkok. Thailand (DEStech Publications, Inc. Pennsylvania, 2020)

8. K. Kim, H. Park, H. Kim, Renewable and Sustainable Energy Reviews, 75 (2017)

9. T. Sedash, Financial life, 3 (2014)

10. A.V. Petrushko, N.T. Oboymova, Features of the formation of the market of clothing and textile industry in Russia. URL: http://be5.biz/ekonomika1/r2014/3636.htm

11. Textile industry in Russia: state and development prospects. URL: https://vuzlit.ru/6660/tekstilnaya_otrasl_rossii_sostoyanie_i_perspektivy_razvitiya

12. Features of the placement of textile industries. URL: http://www.geoguides.ru/guides1096-2.html

13. Innovative textiles: Actual Russian developments in light industry. URL: https://infourok.ru/statya-na-temu-innovacionniy-tekstil-aktualnie-rossiyskierazrabotki-v-legkoy-promishlennosti-3302617.html

14. S.A. Filin, L.A. Chaykovskaya, Journal of Corporate Finance Research, 1 (13) (2018)

15. E. Trukhanova, We will be sewing. 09.15.2015. URL: https://rg.ru/2015/09/15/regcfo/textil.html

16. K.A. Malyuga, Scientific Review, 2 (2015)

17. A.A. Kudryashov, Mechanism of attraction of investments perfection using options for innovative development in RF economy, book 3 (Russian economic academy, Moscow, 2007) 